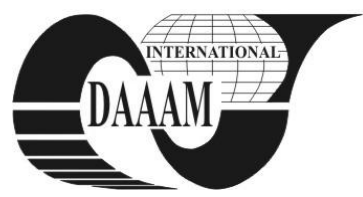

Annals of DAAAM for 2011 \& Proceedings of the 22nd International DAAAM Symposium, Volume 22, No. 1, ISSN 1726-9679 ISBN 978-3-901509-83-4, Editor B. Katalinic, Published by DAAAM International, Vienna, Austria, EU, 2011 Make Harmony between Technology and Nature, and Your Mind will Fly Free as a Bird

\title{
EMPLOYERS' EVALUATION OF ONLINE EDUCATION
}

\author{
VUKELIC, B[ernard] \& POGARCIC, I[van]
}

\begin{abstract}
The role of education is constantly changing. Apart from listening to lectures in a classroom, students can also attend online classes and take online tests. Numerous institutions offer online studies, but the problem is that many of them are anonymous and the value of degrees they provide is questionable. So, numerous employers refuse to employ a person with an online degree because they cannot estimate their level of knowledge and skills based on this degree. This paper will present the results of a research conducted in companies in Primorsko-goranska County, regarding employers' opinion on online degrees
\end{abstract}

Key words: online education, online studies, online degrees, employers, online courses

\section{INTRODUCTION}

A degree is the evidence that a person possesses certain amount of knowledge and skills. Although, in the modern society, the process of education still implies educating students in formal circumstances (schools, universities), the lifelong education is becoming more important in both formal and informal environment. Young and older people seek for knowledge on the Internet, exploring different sources. Due to new technologies, the teaching process doesn't require the student to be at a certain place at a certain moment. The majority of faculties, including the Polytechnics of Rijeka, offer their students a form of online classes using tools like WebCT, Moodle, Blackboard, etc.

But, it has been noticed that there is a rise in a number of academic institutions and higher education institutions worldwide which offer education through the Internet and enable students earning a degree, M.A. degree or even a $\mathrm{PhD}$ online. The number of these institutions is large, and it is interesting that certain institutions with a reputation in formal education started offering their students the possibility of earning an online degree.

The research which was conducted for the needs of this article included employers' opinion on this subject. Their viewpoint is important because they are potential employers of all the students of the Polytechnics of Rijeka. Also, all the companies they work in or own are placed in Primorskogoranska County.

\section{ONLINE EDUCATION}

The topic of online education was very interesting to numerous authors who have already written many papers regarding this subject. The majority of them listed positive and negative aspects of online education and compared it to classic form of education (Kearsley, 1999). A large number of authors presented positive aspects of online education, giving more positive reasons why students and institutions should choose and offer online courses.

Higher education institutions also need to consider whether they are ready to meet growing learner demands in the coming years (Bonk \& Kyong-Jee, 2006). They have all agreed that there are some disadvantages of online education, but they didn't find them as important as the positive ones (Volery \& Lord, 2000).

An article which presented this topic was used as a preresearch for writing this one (Pašić, 2002). The author answered a large number of questions about online education and explained under which conditions students can study. Also, the author listed the institutions which offer online studies and the fields of studies. In the article, it was also explained which qualifications students need in order to attend online courses.

\section{THE RESEARCH}

The main objective of this research was to explore employers' opinion on online degrees. Therefore, 20 employers were interviewed. The questions were about their knowledge of online studies, their opinion on this type of education and their experience with enlisting potential employees. The pattern wasn't numerous $(n=20)$, but it was representative, considering the fact that all the interviewed employers had similar viewpoints. Also, they all own small and medium-sized enterprises. People who were interviewed work as managers or in human resources. The fields are also different - paper industry, finance, pharmacy and ICT.

The employers had a common opinion on degrees (Fig.1): The majority of them $(90 \%)$ consider that degree doesn't provide sufficient evidence that a person is an expert and that he or she possesses the required knowledge or skills. So, they all conduct their own researches within their companies and give the potential employees additional tests, which are conducted by human resources experts. Also, they often employ people on probation.

Does a degree guarantee that students achieve the necessary knowledge and skills, when looking for employees?

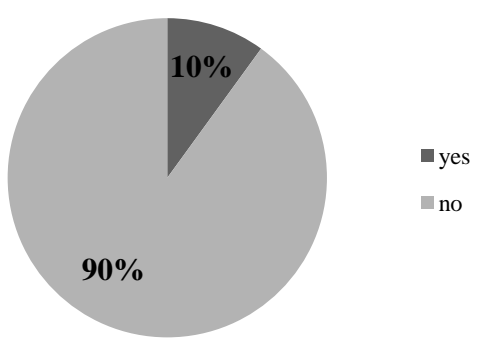

Fig. 1. Employers' opinion on significance of online degrees regarding knowledge and skills

Many employers have negative attitude towards online degrees (Fig. 2.) because they believe that the students are not 
being observed while taking tests. Furhthermore, these degrees have to be verified and signed in the labour book.

The employers who were interviewed described some of their experience with the people who brought their online degrees on job interviews. They were not different from the classic degrees, so the employers couldn't see the difference. Also, some of the candidates printed the degrees in their own homes, so they lacked a formal signature of the institution. Tradition and reputation of these institutions are of major importance to the employers. Many of them stated that some of these institutions are unknown to them, so it was impossible to estimate whether these degrees are based on real knowledge and skills or not.

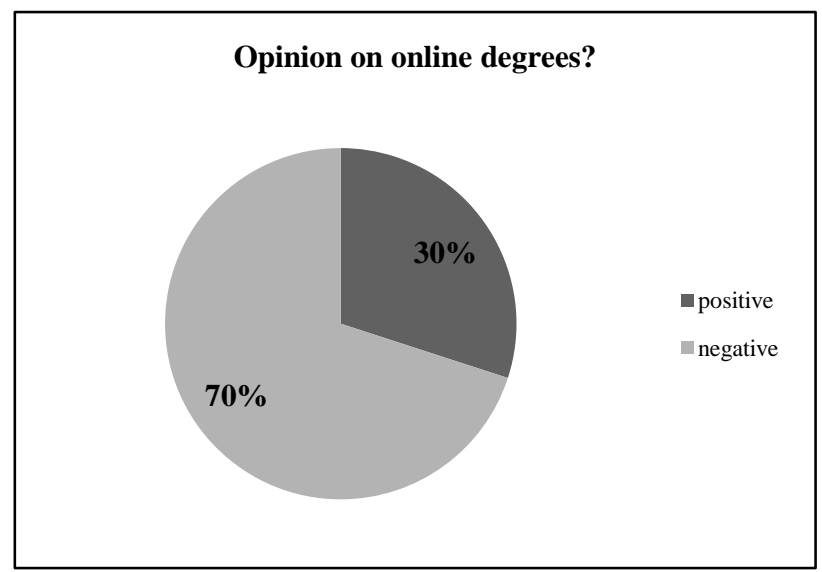

Fig. 2. Employers' opinion on online degrees, regarded as positive or negative

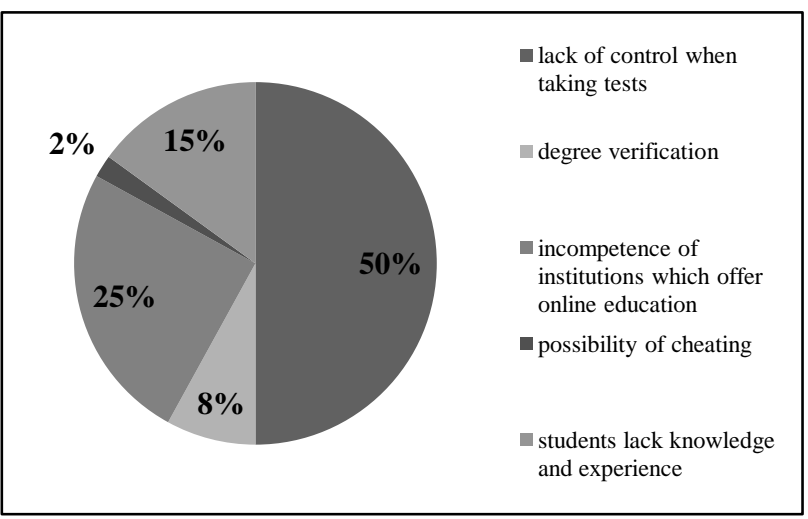

Fig. 3. Employers' opinion on disadvantages of online education

Considering online education, some of the employers offer their employees online courses (Fig. 4.) as the possibility of further education $(40 \%)$.

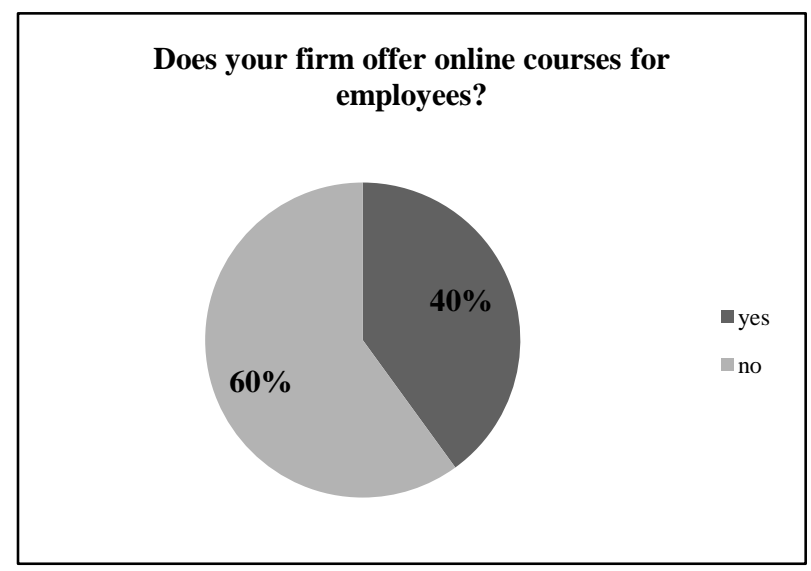

Fig. 4. The percentage of companies which offer online courses for their employees
In their opinion (Fig. 5.), a great advantage of online education is the possibility of attending lectures through videoconferences, conducted by famous experts in the fields.

Furthermore, this form of education can save them time because the employees who attend these courses don't have to leave their offices in order to attend the lecture. Also, it is possible to educate a large number of employees at the same time, with minimal costs.

\section{Reasons for choosing online course instead the classical one}
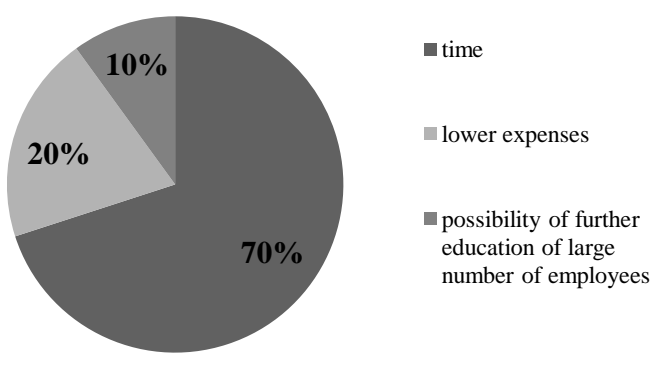

Fig. 5 The reasons why certain employers choose online course instead the classical one

However, some employers had different viewpoints. For example, the employers in ICT companies stated that it didn't matter that much to them whether a candidate has a classic or an online degree. On the other hand, the employers who work in management think that only the traditional form of education can provide the students certain skills of communication, eloquence and presentation. Their standpoint is that managers need to acquire a set of skills in communication and social interaction, which cannot be acquired if a student doesn't leave his or her room.

\section{CONCLUSION}

The research results showed that the majority of employers who were interviewed have a negative attitude towards online education in general. There are numerous factors which affect their viewpoints, which were explained in this article.

Questions that arise in the end are the following: should faculties and employers have equal attitudes towards online education and could the usage of new technologies be an obstacle or an advantage in their communication? The time will tell.

\section{REFERENCES}

Bonk, C.J. \& Kyong-Jee, K. (2006): The future of online teaching and learning in higher education, Available from: http://faculty.weber.edu/eamsel/Research Groups/On-line Learning/Bonk (2006).pdf Accessed: 2011-05-21

Kearsley, G. (1999): Online education: Learning and teaching in cyberspace, Wadsworth Thomson Learning, ISBN 0534506895, Belmont

Mayadas, et al. (2009): Online Education Today, Science 2, Vol. 323 Iss: 5910, pp.85-89

Pašić D. (2002): Želim diplomirati putem interneta, CARNet Časopis Edupoint, Vol. 2 Iss: 4, ISSN 1333-5987, pp.1 - 4, Zagreb

Volery, T. \& Lord, D., (2000): Critical success factors in online education, International Journal of Educational Management, Vol. 14 Iss: 5, ISSN: 0951-354X, pp. 216 223 